\title{
PREVALENCE OF ECTOPARASITES IN CATTLE (BOS INDICUS) OF JESSORE, BANGLADESH
}

\author{
Sharmin Musa*, Tania Ahmed and Hamida Khanum \\ Parasitology Branch, Department of Zoology, University of Dhaka, \\ Dhaka-1000, Bangladesh
}

\begin{abstract}
A study was carried out on 60 cattle and $34(56.66 \%)$ were found infested with ticks and lice. Mean parasitic burden was $2.26 \pm 0.37$ per square inches in cattle. Two species of arachnids, Haemaphysalis bispinosa (31.66\%) and Rhipicephalus sanguineus (28.33\%) lice, Linognathus vituli (23.33\%) were identified. Mean parasitic burden was high in case of $R$. sanguineus $(4.33 \pm 0.48)$ followed by $H$. bispinosa $(2.89 \pm 0.62)$ and least in $L$. vituli $(1.28 \pm 0.16)$. Prevalence of ectoparasites were relatively higher in young animals aged $>1-3$ year $(66.66 \%)$ followed by in calf aged $\leq 1$ year $(50 \%)$ and lowest in adult aged $>3$ year $(44.44 \%)$ in cattle. The mean parasitic burden was higher in case of young $(2.8 \pm 0.60)$ followed by adults $(1.75 \pm 0.41)$ and calves $(1.5 \pm 0.34)$. Infestation was higher in female $(64.10 \%)$ than the male $(42.85 \%)$. Prevalence of ectoparasites were relatively higher in summer $(75 \%)$ followed by in winter $(55 \%)$ and lowest in rainy season $(40 \%)$. The mean parasitic burden was highest in summer $(1.93 \pm 0.64)$ followed by in winter $(1.72 \pm 0.54)$ and lowest in rainy season $(1.5 \pm 0.50)$.
\end{abstract}

Key words: Prevalence, Ectoparasites, Cattle

\section{INTRODUCTION}

The economy of Bangladesh largely depends on agriculture; livestock being one of the four components of agriculture (crops, livestock, fisheries and forestry) plays a vital role in national economy, contributing about $2.93 \%$ of gross domestic products (GDP) in Bangladesh (Anon. 2007). Cattle are the main source of animal protein as they provide meat, milk and source of draft power and hides. The animal is also used for transportation, threshing and crushing of crops. In addition, cattle by product e.g. dung are used as fuel and manure; bone, horn and teeth for making comb. From cattle, Bangladesh gets 173 thousand metric tons beef and 782 thousand metric tons milk per year (Anon. 2008). But cattle rearing is hindered by various problems among them malnutrition and parasitic infestation are the major limiting factors especially in Bangladesh (Jabbar and Green 1983).

Ectoparasitic infestation is one of the major problems in veterinary affecting livestock industries in many parts of the world (Hourrigan 1979). The climate condition of Bangladesh is very conducive to a variety of parasites as well as

*Author for correspondence: <sharminsumi@yahoo.com>

(c) 2018 Zoological Society of Bangladesh DOI: http://dx.doi.org/10.3329/bjz.v46i2.39047 
ticks (Razzak and Shaikh 1969). Poor nutrition, intensity of sunlight, temperature, humidity, crowding, management conditions, host skin reaction, hair condition, hair length and shedding, animal grooming, licking, physiological resistance, breeds, etc. contribute to lice infestation which is the constrain of cattle production (Hussain et al. 2005).

Ticks are annoying pests but in temperate and tropical countries they surpass all other arthropods in number and variety of diseases which they transmit to man and to other domestic stock (Torina et al. 2006). Heavy infestation of ticks cause severe irritation, which makes the animals to rub and scratch the skin that might result in loss of hairs. The skin becomes inflamed, corrugated and scaly which subsequently results in dermal lesions. Ticks induce a direct effect on the availability of good quality hides and skins to leather industry.

On the other hand, lice infestations also decrease vigor and lower reproductive capacity of the amimals. Lice transmit from one host to another by direct contact or hair containing lice pulled out by the infested hosts. Lice can have a significant effect on milk production and weight gain (Loomis 1986). In recent years, hide damage caused by lice has been increasingly recognized as a significant effect of lice infestations (Webster and Bugby 1990).

Considering economic importance and health effects emphasis has been given to the control of this malady. Although, the prevalence and intensity of ectoparasites vary from region to region, district to district even place to place within a country, it is considered as a prerequisite for planning an effective control measures. Since no studies have been undertaken in Jessore, considering all these points, the present study was undertaken to determine the prevalence of ectoparasites in relation to age, sex and seasonal dynamics.

\section{MATERIAL AND METHODS}

The present study was conducted on 60 cattle and samples were selected from Kotawali thana of Jessore district for the convenience of the study and availability of the cattle. Parasitological examination was conducted in the Department of Zoology, University of Dhaka. The investigation was carried out during the period from February, 2010 to January, 2011. So the experimental period was divided into these three seasons summer (March-June), rainy (JulyOctober) and winter. The age of the cattle was above 6 months and was determined by examining the teeth (Bugby and Webster 1990) and birth record. The cattle were categorized into three groups: calf $(\leq 1$ year), young $(>1-3$ years) and adult ( $>3$ years) animals. 
Ectoparasites were collected from the different parts of the body of the individual cattle by hand picking. When required, small hairbrush dipped in ethanol was used for the collection of ectoparasites. The point of attachment was smeared with ethanol. Parasites were preserved in $70 \%$ alcohol in clean and identified according to the keys and descriptions given by Wall and Shearer (1997) and Soulsby (1982) and by preparing permanent slides following the procedures described by Cable (1967).

\section{RESULTS AND DISCUSSION}

In the present study, a total of 60 cattle were examined of which 34 (56.66\%) were found infested with one or more species of ticks and lice. Two species of arachnids, namely Haemaphysalis bispinosa (31.66\%), Rhipicephalus sanguineus $(28.33 \%)$ and and 1 species of lice, namely Linognathus vituli $(23.33 \%)$ were identified. The range of ectoparasitic burden in case of Haemaphysalis bispinosa was 1 - 9 per square inches of heavily infested area followed by Rhipicephalus sanguineus ( 1 - 7) and Linognathus vituli ( 1 - 3) and mean intensity was also higher in case of $R$. sanguineus (4.33 \pm 0.48 ) followed by $H$. bispinosa $(2.89 \pm 0.62)$ and least in $L$. vituli $(1.28 \pm 0.16)$. The standard deviation was higher in case of $H$. bispinosa ( \pm 2.74 ) followed by $R$. sanguineus $( \pm 1.99)$ and L. vituli $( \pm 0.61)$ (Table 1$)$.

Table 1. Prevalence of ectoparasites in cattle

\begin{tabular}{|c|c|c|c|c|c|c|}
\hline \multirow{2}{*}{$\begin{array}{l}\text { No. of cattle } \\
\text { examined }\end{array}$} & \multirow{2}{*}{$\begin{array}{l}\text { Name of } \\
\text { ectoparasites }\end{array}$} & \multirow{2}{*}{$\begin{array}{c}\text { No. of } \\
\text { cattle } \\
\text { affected }\end{array}$} & \multirow{2}{*}{$\begin{array}{c}\text { Prevalence } \\
\text { (\%) }\end{array}$} & \multicolumn{2}{|c|}{ Parasitic burden } & \multirow[t]{2}{*}{$\pm \mathrm{SD}$} \\
\hline & & & & Range & Mean $\pm \mathrm{SE}$ & \\
\hline 60 & H. bispinosa & 19 & 31.66 & $1-9$ & $2.89 \pm 0.62$ & \pm 2.74 \\
\hline 60 & R. sanguineus & 17 & 28.33 & $1-7$ & $4.33 \pm 0.48$ & \pm 1.99 \\
\hline 60 & L. vituli & 14 & 23.33 & $1-3$ & $1.28 \pm 0.16$ & \pm 0.61 \\
\hline 60 & Total & $34^{*}$ & 56.66 & $1-9$ & $2.26 \pm 0.37$ & \pm 2.19 \\
\hline
\end{tabular}

* = Total no. of animals affected is less than the summation of individual infestation because same animal was infested by more than one type ticks and lice.

Aydin et al. (2006) in South eastern Bulgaria, Rahbari et al. (2007) in Iran also reported 56.33, 57.93 and $62.00 \%$ tick infestation in cattle. Higher prevalence was reported by several authors, such as Swai et al. (2005) in Tanzania, Ghosh et al. (2007) in South Asia and Sajid et al. (2008) and 85.6, 80 and $75.1 \%$, respectively. In Pakistan, Ramzan et al. (2008) found prevalence of ticks, mites and lice was 36, 5 and 8\%, respectively. Stuti et al. (2008) recorded $37.32 \%$ cattle infested with ticks in foothills of Uttarakhand State, India. In Bangladesh Roy et al. (2000) in Madhupur and Kabir (2009) in Chittagong, reported 28.2 and $36.31 \%$ prevalence of tick infestation respectively, in cattle. 
Islam et al. (2009) reported Haemaphysalis bispinosa (7.8\%) and Rhipicephalus sanguineus (10.6\%) in Sirajgong. Rony et al. (2010) found Rhipicephalus sanguineus (36.89\%) and Haemaphysalis bispinosa (16.50\%) in cattle in Gazipur district. Khanum et al. (2013) found 63.33\% arthropod infetation in cattles from Dhaka city. The differences between result of present and earlier studies may be due to variation in geographic locations, climatic conditions of the experimental area and also breeding and rearing procedure of the study animals.

Prevalence of ectoparasites was relatively higher in young animals aged $>1-3$ year (66.66\%) followed by in calf aged $\leq 1$ year (50\%) and lowest in adult aged $>3$ year (44.44\%). (Table 2). In case of calves $R$. sanguineus (25\%) showed highest prevalence followed by that of $H$. bispinosa (25\%) and $L$. vituli $(16.66 \%)$. (Table 2). In young cattle higher prevalence was seen in case of $H$. bispinosa (36.66\%), followed by that of $R$. sanguineus (33.33\%) and L. vituli (30\%) (Table 2). Prevalence of ticks and lice in adult were higher in case of $\mathrm{H}$. bispinosa (27.77\%), followed by that of $R$. sanguineus (22.22\%) and L. vituli (16.66\%) (Table 2).

Table 2. Age related prevalence of ectoparasites in cattle.

\begin{tabular}{|c|c|c|c|c|c|c|c|}
\hline \multirow{2}{*}{$\begin{array}{l}\text { No. of cattle } \\
\text { examined }\end{array}$} & \multirow{2}{*}{$\begin{array}{l}\text { Age of } \\
\text { cattle }\end{array}$} & \multirow{2}{*}{$\begin{array}{l}\text { Name of ticks and } \\
\text { lice recovered }\end{array}$} & \multirow{2}{*}{$\begin{array}{c}\text { No. of } \\
\text { cattle } \\
\text { affected }\end{array}$} & \multirow{2}{*}{$\begin{array}{c}\text { Prevalence } \\
\text { (\%) }\end{array}$} & \multicolumn{2}{|c|}{ Parasitic burden } & \multirow[t]{2}{*}{$\pm \mathrm{SD}$} \\
\hline & & & & & Range & Mean $\pm \mathrm{SE}$ & \\
\hline \multirow{3}{*}{12} & \multirow[t]{3}{*}{$\begin{array}{l}\text { Calf } \\
\text { ( } \leq 1 \text { year })\end{array}$} & $\begin{array}{l}\text { Haemaphysalis } \\
\text { bispinosa }\end{array}$ & 3 & 25 & $1-2$ & $1.33 \pm 0.32$ & \pm 0.57 \\
\hline & & $\begin{array}{l}\text { Rhipicephalus } \\
\text { sanguineus }\end{array}$ & 3 & 25 & $1-3$ & $1.66 \pm 0.66$ & \pm 1.15 \\
\hline & & Linognathus vituli & 2 & 16.66 & $1-2$ & $1.5 \pm 0.49$ & \pm 0.70 \\
\hline \multirow{3}{*}{30} & \multirow{3}{*}{$\begin{array}{l}\text { Young } \\
(>1-3 \\
\text { years })\end{array}$} & $\begin{array}{l}\text { Haemaphysalis } \\
\text { bispinosa }\end{array}$ & 11 & 36.66 & $1-9$ & $4.27 \pm 0.88$ & \pm 2.93 \\
\hline & & $\begin{array}{l}\text { Rhipicephalus } \\
\text { sanguineus }\end{array}$ & 10 & 33.33 & $1-7$ & $3.1 \pm 0.72$ & \pm 2.28 \\
\hline & & Linognathus vituli & 9 & 30 & $1-3$ & $1.44 \pm 0.24$ & \pm 0.72 \\
\hline \multirow{3}{*}{18} & \multirow{3}{*}{$\begin{array}{l}\text { Adult } \\
(>3 \\
\text { years })\end{array}$} & $\begin{array}{l}\text { Haemaphysalis } \\
\text { bispinosa }\end{array}$ & 5 & 27.77 & $1-4$ & $2.2 \pm 0.58$ & \pm 1.30 \\
\hline & & $\begin{array}{l}\text { Rhipicephalus } \\
\text { sanguineus }\end{array}$ & 4 & 22.22 & $1-3$ & $1.75 \pm 0.47$ & \pm 0.95 \\
\hline & & Linognathus vituli & 3 & 16.66 & $1-1$ & $1.00 \pm 0.00$ & \pm 0.00 \\
\hline
\end{tabular}

In the present study it can be revealed that age of cattle had a significant effect on ticks and lice infestation. Young cattle had more parasite infestation compare to calves and adult cattles. Rony et al. (2010) also found mean tick burden was higher in adult followed by old and young calves. Islam et al. (2009) found higher prevalence in old cattles compared to young and adult. Yakhchali et al. (2011) found that tick infestation was higher in adult cattles $(60.8 \%)$ than 
in calves (20\%) in Oshnavich. Swai et al. (2005) showed that mature animals had higher prevalence of ticks than young stock in Tanzania. The percentage of infestation of ticks on adult cattle was higher than in young cattle as observed by Razzak and Shaikh (1969) in Pakistan. In contrast, Stuti et al. (2008) reported the highest prevalence in one year calves below one year (65.38\%) followed by grownups (34.60\%) and adults (14.91\%) cattle. Khanum et al. (2013) also found higher prevalence in calves (84.61\%).

In the study, it was detected that the prevalence of ectoparasitic infestation was higher in female $(64.10 \%)$ than the male $(42.85 \%)$ cattle. The mean parasitic burden was higher in female $(2.52 \pm 0.49)$ than in male $(2.22 \pm 0.49)$. (Table 3$)$. In male highest prevalence was of $H$. bispinosa (23.81\%), followed by that of $R$. sanguineus (19.04\%) and L. vituli (14.28\%) (Table 3). Prevalence of ticks and lice were higher in female in case of $H$. bispinosa $(23.81 \%)$, followed by that of $R$. sanguineus (19.04\%) and L. vituli (14.28\%) (Table 3). These results confirm the reports of Baroi (2009), Sarkar (2007), Kabir et al. (2011) and Rony et al. (2010) who reported the prevalence of ectoparasites was significantly higher in female than male in Bangladesh. Although the exact cause of higher prevalence of ectoparasites infestation in female cattle cannot be explained but it can be hypothesized that some hormonal influences as well as stress factors (pregnancy, lactation etc.) leading to immune suppression may be associated with this phenomenon. Lyod (1983) reported that higher level of prolactin and progesterone hormones make the female individual more susceptible to any infection. Different results were found in Khanum et al. (2013) where male cattle had higher infection rates.

Table 3. Prevalence of ectoparasites in male and female cattle

\begin{tabular}{|c|c|c|c|c|c|c|c|}
\hline \multirow{2}{*}{$\begin{array}{l}\text { Sex of } \\
\text { cattle }\end{array}$} & \multirow{2}{*}{$\begin{array}{l}\text { No. of cattle } \\
\text { examined }\end{array}$} & \multirow{2}{*}{$\begin{array}{l}\text { Name of ticks } \\
\text { and lice } \\
\text { recovered }\end{array}$} & \multirow{2}{*}{$\begin{array}{c}\text { No. of } \\
\text { cattle } \\
\text { affected }\end{array}$} & \multirow{2}{*}{$\begin{array}{c}\text { Prevalence } \\
(\%)\end{array}$} & \multicolumn{2}{|c|}{ Parasitic burden } & \multirow[t]{2}{*}{$\pm \mathrm{SD}$} \\
\hline & & & & & Range & Mean \pm SE & \\
\hline Male & 21 & H. bispinosa & 5 & 23.81 & $1-5$ & $3.00 \pm 0.70$ & \pm 1.58 \\
\hline Female & 39 & & 14 & 35.89 & $1-9$ & $3.57 \pm 0.78$ & \pm 2.92 \\
\hline Male & 21 & $R$. sanguineus & 4 & 19.04 & $1-4$ & $2.5 \pm 0.64$ & \pm 1.29 \\
\hline Female & 39 & & 13 & 33.33 & $1-7$ & $2.61 \pm 0.60$ & \pm 2.18 \\
\hline Male & 21 & L. vituli & 3 & 14.28 & $1-2$ & $1.66 \pm 0.32$ & \pm 0.57 \\
\hline Female & 39 & & 11 & 28.20 & $1-3$ & $1.27 \pm 0.19$ & \pm 0.65 \\
\hline
\end{tabular}

Prevalence of ectoparasites was relatively higher in summer season $(75 \%)$ followed by in winter (55\%) and lowest in rainy season (40\%). The mean intensity was highest in summer (1.93 \pm 0.64$)$ followed by in winter (1.72 \pm 0.54$)$ and lowest in rainy season (1.5 \pm 0.50$)$ (Fig. 1). H. bispinosa $(45 \%)$ was higher in 
summer season followed by that of $R$. sanguineus (20\%) and L. vituli (10\%). (Fig. $1)$. In winter prevalence was higher in case of $R$. sanguineus (50\%), followed by that of $H$. bispinosa (35\%) and L. vituli (35\%) (Fig. 1).

\section{Prevalence}

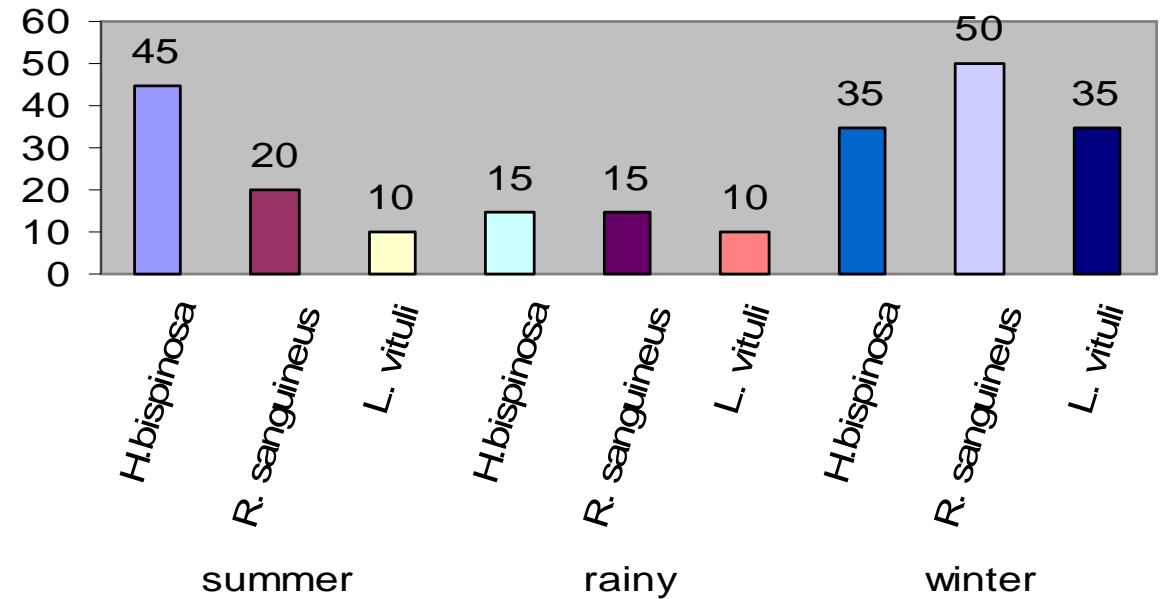

Fig. 1. Season related prevalence of ectoparasites in cattle.

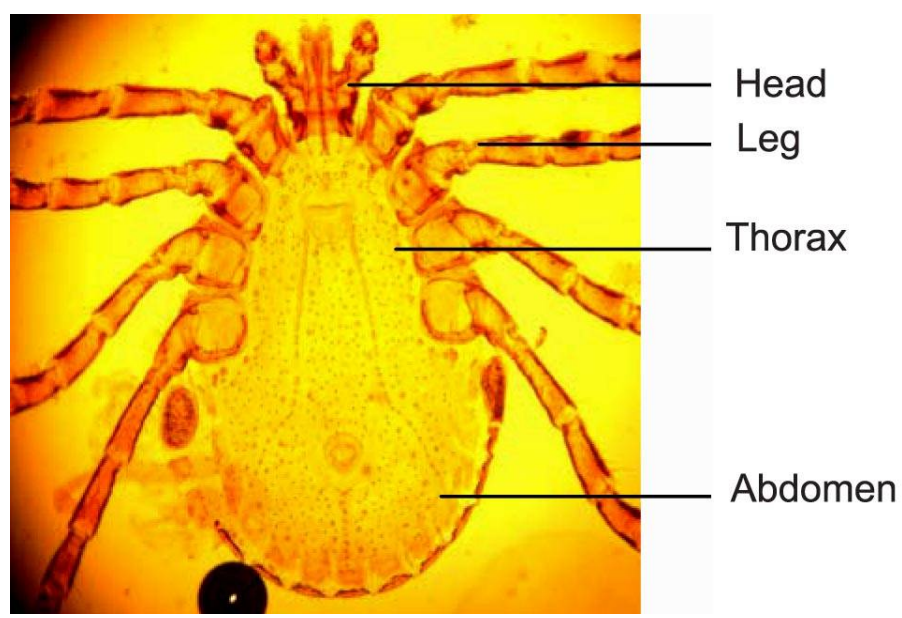

Fig. 2. Full view of Haemaphysalis bispinosa (100X).

The present study revealed significant effect of seasonal fluctuation on the prevalence ectoparasitic infestation in cattle. The prevalence of ectoparasitic infestation was significantly higher during the summer and winter season as compared to the rainy season in cattle. Similar information was provided with Islam et al. (2009) who reported higher prevalence of ectoparasites in summer 
season than winter. Kamal et al. (1996) reported the highest tick infestation rate in the summer, which declined gradually through the rainy season to its level in winter. Sanjay et al. (2007) reported the seasonal prevalence of tick infestation significantly more during the rainy and summer season as compared to the winter season. He also reported lice infestation significantly higher in winter than in the rainy and summer seasons Kabir et al. (2011), Rony et al. (2010) and Khanum et al. (2013) also reported higher prevalence of ectoparasites during summer in cattle in Bangladesh.

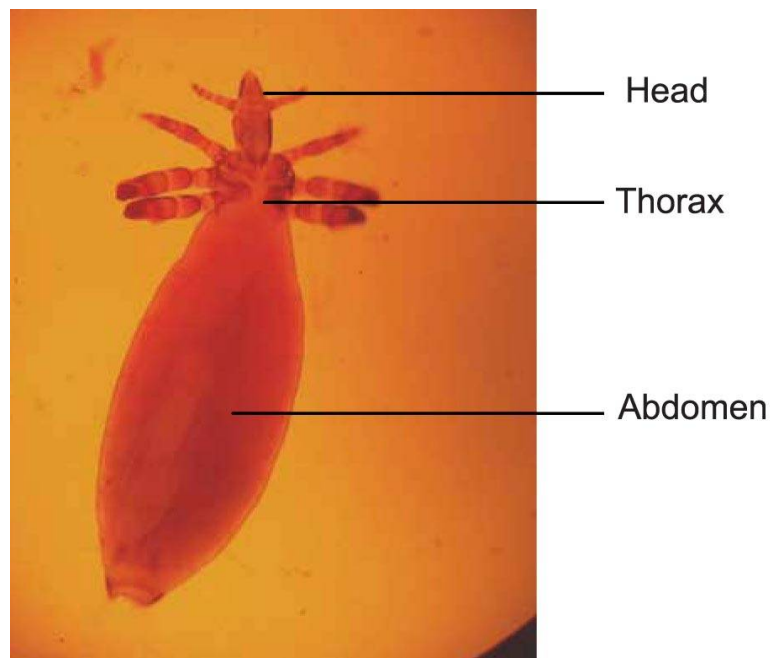

Fig. 3. Full view of Linognathus vituli (100X).

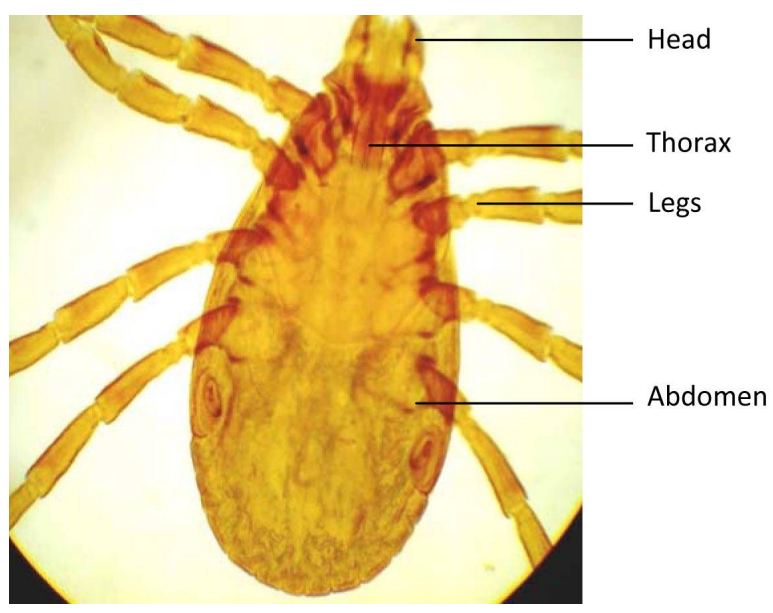

Fig. 4. Full view of Rhipicephalus sanguineus (100X). 
The contrast between the present and earlier findings can be explained by the fact of variation of geographical location of experimental area, topography, the composition of soil type and humidity, lack of control group of population and most importantly, the changed climatic condition of the earth.

The observations from the present study may contribute to the increased understanding of the epidemiology of ectoparasites affecting buffaloes in Bangladesh, so that, control strategies can be suggested. However, during this study, only two species of ticks and one species of lice were detected but no mites and flies were recorded. Further studies should be conducted to identify those ectoparasites.

\section{LITERATURE CITED}

ANON. 2007. Bangladesh Arthonaitik Shamikkha. Ministry of Finance, Government of the People's Republic of Bangladesh, Dhaka, Bangladesh. pp. 81.

ANON. 2008. Bangladesh Economic Review, Economic Advisor Wing Finance Division, Ministry of Finance, Goverment of the People's Republic of Bangladesh. pp. 96.

AYDIN, L., P PRELOSOV, S BAKIRCI and SENLIK, B. 2006. Ixodid ticks on cattle and sheep in South Eastern Bulgaria. Indian Vet. J. 83(7): 802.

BAROI, S.K. 2009. Prevalence of ticks in cattle and goats in Char Bhadrasan of Fridpur, Bangladesh. MS Thesis, Department of Parasitology, Bangladesh Agricultural University, Mymensingh.

BUGBY, A. WEBSTER, R.M. and TICHENER, R.N. 1990. Light spot and fleck grain defects of economic importance to the UK leather industry, part 1; identification of causal agent. Laboratory report 184. British Leather Confederation, Northampton.

CABLE, R.M. 1967. An Illustrated Laboratory Manual of Parasitology, 4th edition, Burgress Publishing Co., Minneapolis, Minnesota, USA. pp. 111-131.

GOSH S., BANSAL, G.C., GUPTA, S.C., RAY, D., KHAN, M.Q, IRSHAD, H., SHAHIDUZZAMAN, M., SEITZER, U and AHMED, J.S. 2007. Status of tick distribution in Bangladesh, India and Pakistan. Parasitol Res. 101: 207-216.

HOURRIGAN, J.L. 1979. Spread and detection of Psoroptic scabies of cattle in the United States. JAVMA 175: 12781280.

HUSSAIN, M.A., KHAN, M.N., IQBAL, Z. and SAJID, M.A. 2005. Prevalence and chemotherapy of lice infestation in bovines. Int. J. Agric. Biol. 7(4): 694-697.

ISLAM, M.S., RAHMAN, S.A., SARKER, P., ANISUZZAMAN and MONDAL, M.M.H.. 2009. Prevalence and population density of ectoparasitic infestation in cattle in Sirajgonj district: Bangladesh. Bangl. Res. Pub. J. 2(1): 332-339.

JABBAR, M. and. GREEN, D.A.G. 1983. The status and potential of livestock within the context of agricultural development policy in Bangladesh. Ph.D Thesis, The University of Wales, Aberyswyth, UK. pp. 113.

KABIR, M. H. B., MONDAL, M. M. H., EliYAS, M., MANNAN, M. A., HASHEM, M. A., DEBNATH, N. C., MIAZI, O. F., MOHIUDDIN, C., KASHEM, M. A., ISLAM, M. R. and ELAHI, M.F. 2011. An epidemiological survey on investigation of tick infestation in cattle at Chittagong district, Bangladesh. Afr. J. Microbiol. Res. 5(4): 346-352. 
KAMAL, A.H.M., UDDIN, K.H., ISLAM, M.M. and MONDAL, M.M.H. 1996. Prevalence of economically important ticks in cattle and goat at Chittagong hilly areas of Bangladesh. Asian Australasian J. Anim. Sci. 9: 567-569.

KHANUM, H., YEASMIN, T., ZAMAN, R.F. and MUSA, S. 2013. Infestation of arthropod parasites in cattle and sheep. J. Nat. Hist. 9(2): 5-12.

Lloyd, S. 1983. Effect of pregnancy and lactation up on infection. Vet. Immunol. Immunopathol. 4: 153-176.

LOOMIS, E.C. 1986. Ectoparasites of cattle. Vet. Clin. North America. 2: 299-321.

RAHBARI S., NABIAN, S. and SHAYAN, P. 2007. Primary report on distribution of tick fauna in Iran. Parasitol. Res. 2: 175-177.

RAMZAN, M., KHAN, M.S., AVAIS, M., KHAN, J. A., PERVEZ, K. and SHAHZAD, W. 2008. Prevalence of ectoparasites and comparative efficacy of different drugs against tick infestation in cattle. $J$. Anim. Plant Sci. 18(1): 17-19.

RAZZAK, A and SHAIKH, H. 1969. A survey on the prevalence of ticks on cattle in East Pakistan. Pak. Vet. J. 3: 54-60.

RONY, S. A., MONDAL, M. M. H., BEGUM, N., ISLAM, M. A. and AFFROZE, S. 2010. Epidemiology of ectoparasitic infestations in cattle at Bhawal forest area, Gazipur Bangl. J. Vet. Med. 8(1): 2733.

ROY, A.K., RAHMAN, M.H., MAJUMDER, S. and SARKAR, A.S. 2000. Ecology of ticks ad tick-borne blood protozoa in Modhupur forest area Tangail. Bangl. J. Vet. Med. 17: 90-97.

SAJID, MS., IQBAL, Z., KHAN, M.N and MUHAMMAD, G. 2008. Point prevalence of hard ticks (Ixodids) infesting domestic ruminants of lower Punjab, Pakistan. Int. J. Agri. Bio. 10: 349-351.

SANJAY, K., PRASAD, K.D and. DEB, A.R. 2007. Seasonal prevalence of different ectoparasites infecting cattle and buffaloes. J. Res. 16(1): 159-163.

SARKAR, M. 2007. Epidemiology and pathology of ectoparasitic infestation in Black Bengal Goats in Bangladesh. M.Sc. thesis. Department of Parasitology, Bangladesh Agricultural University, Mymensingh.

SOULSBY, E. J. L. 1982. Helminths Arthropods and Protozoa of Domesticated Animal. $7^{\text {th }}$ Edition, Bailliere Tindal, London, pp: 136-346, 365-491 and 763-778.

STUTI, V., YADEV, C.L., KUMAR, R.R. and RAJAT, G. 2008. Prevalence of ixodid ticks on bovines in foothills of Uttarkhand state, Indian. Indian J. Anim. Sci. 78(1):40-42.

SWAI, E.S., MBISE, A.N., KESSY, V., KAAYA, E., SANKA, P. and LOOMU, P.M. 2005. Farm constraints, cattle disease perception and tick management practices in pastoral Maasai community-Ngorongor, Tanzania. Livestock. Res. Rural. Dev. 17(2): 17-20.

TORINA, A., KHOURY, C., CARACAPPA, S. and MAROLI, M. 2006. Ticks infesting livestock on farms in Western Sicily, Italy. Exp. Appl. Acarol. 38(1): 75-86.

WALL, R. and SHEARER, D.1997. Veterinary Entomology, $1^{\text {st }}$ edition, Chapman and Hall, 2-6 Boundary Row, London, pp. 43-135

WEBSTER, R.M. and BUGBY, A. 1990. Light spot and fleck grain defects of economic importance to the UK leather industry, part 1: Identification of causal agent. Laboratory report 184. British Leather Confederation, Northampton.

YAKHCHALI, M., ROSTAMI, A. and ESMAILZADEH, M. 2011. Diversity and seasonal distribution of ixodid ticks in the natural habitat of domestic ruminants in north and south of Iran. Revue Méd. Vét. 162(5): 229-235. 